\title{
A new species of Elachistocleis (Anura: Microhylidae) from the Brazilian Pantanal
}

\author{
Alessandher Piva, ${ }^{1}$ Ulisses Caramaschi, ${ }^{2}$ and Nelson Rufino de Albuquerque ${ }^{3,4}$ \\ ${ }^{1}$ Departamento de Medicina Veterinária, UNISOCIESC, Campus Blumenau, Rua Pandiá Calógeras 272, 89010-350 Blumenau, \\ SC, Brazil. \\ ${ }^{2}$ Departamento de Vertebrados, Museu Nacional, Universidade Federal do Rio de Janeiro, Quinta da Boa Vista, São Cristóvão, \\ 20940-040 Rio de Janeiro, RJ, Brazil. \\ ${ }^{3}$ Universidade Federal de Mato Grosso do Sul, Campus do Pantanal, Avenida Rio Branco 1270, 79304-902 Corumbá, MS, \\ Brazil. E-mail: nelson_rufino@hotmail.com. \\ ${ }^{4}$ Programa de Pós-Graduação em Biologia Animal, Universidade Federal de Mato Grosso do Sul.
}

\begin{abstract}
A new species of Elachistocleis (Anura: Microhylidae) from the Brazilian Pantanal. A new species of Elachistocleis from the Brazilian Pantanal is described. The new species differs from all other Elachistocleis in having the following combination of characters: medium to large-sized species $(26.9-40.3 \mathrm{~mm})$; head length about $89 \%$ of head width; post-commissural gland poorly developed; dorsum in preservative (EtOH $70 \%$ ) slightly rough, grayish, with minute, scattered white dots and a large, elongated dark gray spot on the mid-dorsum and posterior part of head; venter gray or brown with white spots separating dorsal and ventral regions; a single vocal sac dark gray; large, irregular, light cream spot on humerus; large, irregular light cream spots on groin; light cream, irregular stripe on posterior surfaces of thighs; and irregular, light cream spots on the proximal internal surface of each shank. This new species increases the number of Oval frogs for the state of Mato Grosso do Sul to four and demonstrates the value of the single protected area in Corumbá for biodiversity conservation. Continuing field investigations in the Maciço do Urucum are necessary to determine the diversity of the herpetofauna in that region.
\end{abstract}

Keywords: biodiversity, Corumbá, Oval frogs, systematics, taxonomy.

\footnotetext{
Resumo

Uma nova espécie de Elachistocleis (Anura: Microhylidae) do Pantanal Brasileiro. Uma nova espécie de Elachistocleis do Pantanal Brasileiro é descrita. A nova espécie difere de todos os outros Elachistocleis por ter a seguinte combinação de caracteres: espécie de médio a grande porte (26.9$40.3 \mathrm{~mm}$ ); comprimento da cabeça com cerca de $89 \%$ da largura da cabeça; glândula pós-comissural
}

Received 04 September 2017 


\begin{abstract}
pobremente desenvolvida; dorso em preservativo (EtOH 70\%) ligeiramente áspero, acinzentado, com pontos brancos pequenos e dispersos e uma mancha cinza escura alongada, grande no meio do dorso e na parte posterior da cabeça; ventre cinza ou marrom com manchas brancas separando as regiões dorsal e ventral; um único saco vocal cinza escuro; uma mancha creme claro grande e irregular no úmero; manchas creme claro grandes, irregulares na virilha; faixa creme claro irregular nas superfícies posteriores das coxas; e manchas creme claras irregulares na superfície interna proximal de cada membro posterior. Esta nova espécie aumenta o número de rãs ovais para o Estado de Mato Grosso do Sul para quatro e demonstra o valor da única área protegida em Corumbá para a conservação da biodiversidade e a importância de continuar as pesquisas de campo no Maciço de Urucum para determinar a diversidade da Herpetofauna.
\end{abstract}

Palavras-chave: biodiversidade, Corumbá, rã oval, sistemática, taxonomia.

\section{Introduction}

The genus Elachistocleis Parker, 1927 was rendered monophyletic with the transfer of Relictivomer Carvalho, 1954 to its synonymy, resurrecting the combination Elachistocleis pearsei (Ruthven, 1914), and by including Chiasmocleis panamensis Dunn, Trapido, and Evans, 1948 in Elachistocleis (de Sá et al. 2012). Currently, Elachistocleis comprises 17 species of Oval frogs, along with several species that have not been named (Caramaschi 2010, Toledo 2010, Toledo et al. 2010, de Sá et al. 2012). Two distinctive ventral color patterns are recognized in the genus. One has chest and belly immaculate, including E. bicolor (GuérinMéneville, 1838); E. haroi Pereyra, Akmentins, Laufer, and Vaira, 2013; E. helianneae Caramaschi, 2010; E. matogrosso Caramaschi, 2010; and E. muiraquitan Nunes-de-Almeida and Toledo, 2012. A second pattern consists of variable blotches or vermiculations on the belly, encompassing E. bumbameuboi Caramaschi, 2010; E. carvalhoi Caramaschi, 2010; E. cesarii (Miranda-Ribeiro, 1920); E. erythrogaster Kwet and Di-Bernardo, 1998; E. magnus Toledo, 2010; E. panamensis (Dunn, Trapido, and Evans, 1948); E. pearsei (Ruthven, 1914); E. piauiensis Caramaschi and Jim, 1983; E. skotogaster Lavilla, Vaira, and Ferrari, 2003; E. surinamensis (Daudin, 1802); and E. surumu
Caramaschi, 2010 (Toledo et al. 2010, Frost 2017). Elachistocleis ovalis (Schneider, 1799) was considered a nomen dubium, referred to as species inquirenda by Caramaschi (2010), but putatively it is included in the blotched belly group.

These moderately small frogs are found in Trinidad and from Panama and Colombia southward, east of the Andes, to southern Paraguay, southeastern Bolivia, central Argentina, central and southeastern Brazil, and Uruguay (Frost 2017). Although Oval frogs exhibit different degrees of intraspecific variation (Nunes-de-Almeida and Toledo 2012), most species are readily distinguished from one another by their color patterns (e.g., Lavilla et al. 2003, Jansen et al. 2011, Pereyra et al. 2013).

Until recently, only Elachistocleis bicolor and E. ovalis were thought to be present in the state of Mato Grosso do Sul. However, Caramaschi (2010) described E. matogrosso and applied alternate names to all populations previously referred to E. ovalis in Brazil. Toledo et al. (2010) removed E. cesarii from the synonymy of E. bicolor. Currently, only $E$. bicolor, E. cesarii and E. matogrosso are recorded in the Pantanal ecosystem. We use the name E. bicolor sensu Caramaschi (2010).

In 2012 and 2013, specimens of the new species were collected in the region of Parque Municipal de Piraputangas (PMP), in the 
Pantanal of Mato Grosso do Sul, Brazil. The anuran fauna of PMP proved to be more diverse than most previously surveyed sites in the Pantanal of Mato Grosso do Sul, with 27 species recorded to date (Piva 2014). Twenty species from this collection were not recorded in the management plan for implementation of PMP [e.g., Phyllomedusa sauvagii Boulenger, 1882, and Rhinella granulosa (Spix, 1824)] and, among these were three Oval frogs that could not be assigned to any known species. Herein, we describe these individuals as a distinctive member of the genus Elachistocleis.

\section{Materials and Methods}

Three male frogs of the type series were collected in the Parque Municipal de Piraputangas $(\mathrm{PMP})\left(19^{\circ} 16^{\prime \prime} \mathrm{S}, 5^{\circ} 38^{\prime} \mathrm{W}\right.$; datum = WGS 84) by A. Piva on 18 December 2012 and 30 November 2013; the specimens are deposited in Coleção Zoológica de Referência da Universidade Federal de Mato Grosso do Sul, Campo Grande, MS, Brazil (ZUFMS) and Museu Nacional, Universidade Federal do Rio de Janeiro, Rio de Janeiro, RJ, Brazil (MNRJ), with catalog numbers ZUFMS-AMP 924, MNRJ 9100 (formerly ZUFMS-AMP 922) and ZUFMSAMP 923. PMP is a protected area of 1300 ha located approximately $25 \mathrm{~km}$ south of the urban area of Corumbá, state of Mato Grosso do Sul, Brazil. The climate classification of Köppen and Geiger (Peel et al. 2007), identified Corumbá as a tropical dry climate (savannah climate) with average monthly temperature above $18^{\circ} \mathrm{C}$ throughout the year and $1074 \mathrm{~mm}$ of annual precipitation. The current vegetation of the park is semi-deciduous forest; however, large areas have been cleared or heavily modified for pasture or mining activities. Male frogs were collected in a disturbed area of the PMP, characterized by rocky soils and herbaceous strata composed of grasses, and three permanent and several ephemeral ponds. We examined a single female that was collected in the Maciço do Urucum, which is adjacent to PMP.
We compared specimens of the new species with 253 museum specimens of the genus Elachistocleis from the following collections (Appendix I): Museu Nacional, Universidade Federal do Rio de Janeiro, Rio de Janeiro, RJ, Brazil (MNRJ); Coleção Zoológica de Referência da Universidade Federal de Mato Grosso do Sul, Campo Grande, MS, Brazil (ZUFMS); Museu de Zoologia, Universidade de São Paulo, SP, Brazil (MZUSP); Museu de Zoologia "Prof. Adão José Cardoso", Universidade Estadual de Campinas, SP, Brazil (ZUEC); United States National Museum, Smithsonian Institution, Washington, DC, USA (USNM). The description of the new species and comparisons were mostly based on meristic, morphometric, and coloration data, even though literature data (e.g., Ruthven 1914; Lavilla et al. 2003, Caramaschi 2010, Cole et al. 2013, Pereyra et al. 2013) were also considered.

The following measurements (in $\mathrm{mm}$ ) were taken on each specimen of the typeseries: snout-vent length; axilla-groin length; head length, measured diagonally from corner of mouth to tip of snout; head width, between jaw angles; eye diameter; upper eyelid width; eye-naris distance, from anterior corner of eye to center of naris; interorbital distance; narissnout distance, from center of naris to tip of snout; internarial distance, between centers of nares; snout length, from anterior corner of eye to tip of snout; humerus length; forearm length, from flexed elbow to proximal edge of palmar tubercle; hand length, from proximal edge of palmar tubercle to tip of finger IV; thigh length, from vent to knee; shank length, from outer edges of flexed knee to heel; and foot length, from proximal edge of inner metatarsal tubercle to tip of toe IV. Measurements follows Cei (1980) and Heyer et al. (1990), except for axilla-groin length, eye-naris distance and naris-snout distance. We took all measurements $( \pm 0.1 \mathrm{~mm})$ with digital calipers. The typeseries is composed only of adult individuals, as determined by examination of gonads and secondary sex characters. 


\section{Results}

\section{Elachistocleis corumbaensis sp. nov.} Figures 1-4, Table 1

Holotype.-Adult male (ZUFMS-AMP 924): Brazil, state of Mato Grosso do Sul, Corumbá (Parque Municipal de Piraputangas, $19^{\circ} 16^{\prime}$ S, $57^{\circ} 38^{\prime} \mathrm{W}$, datum = WGS 84), collected on 30 November 2013 by Alessandher Piva.

Paratypes.-Same data as holotype, two adult males (MNRJ 91001, formerly ZUFMSAMP 922), collected on 18 December 2012, and ZUFMS-AMP 923, collected on 30 November 2013, by Alessandher Piva. An adult female (ZUFMS-AMP 2595): BrazIL, state of Mato Grosso do Sul, Corumbá (Maciço do Urucum, Córrego das Pedras formation, $19^{\circ} 13^{\prime} \mathrm{S}, 57^{\circ} 38^{\prime}$ $\mathrm{W}$, datum $=$ WGS 84), collected on 15 December 2007 by Liliana Piatti and Paulo Landgref Filho.

Diagnosis._Elachistocleis corumbaensis is a medium to large-sized species (26.9-40.3 mm) that differs from its congeners by the following combination of characters: head length $89 \%$ of head width; post-commissural gland poorly developed; in preservative, dorsum slightly rough, grayish, with scattered minute white dots, and large, elongate darkish spot on the middorsum and posterior part of head; venter gray or brown with white spots separating the dorsal and ventral regions; large, irregular, light cream spot on humerus; large, irregular, light cream spots on groin; irregular light cream stripe on posterior surface of each thigh; irregular, light cream spots on the proximal internal surface of each shank.

Comparisons with other species.-Only Elachistocleis corumbaensis, E. bumbameuboi, and $E$. magnus reach a snout-vent length greater than $40 \mathrm{~mm}$. Furthermore, E. corumbaensis differs from its congeners in having a poorly developed post-commissural gland (well developed in E. bumbameuboi, E. carvalhoi, E. erythrogaster, E. magnus, and E. piauiensis; gland absent in E. skotogaster). The dorsum of $E$. corumbaensis in preservative is grayish, with a large, elongate darkish spot on the mid-dorsum and posterior part of head (elongate darkish spot absent in all other Elachistocleis; this color pattern, easily distinguishes the dorsum of the new species from those of all its congeners, except E. haroi). The dorsum of E. corumbaensis and $E$. pearse $i$ are dotted in white. Otherwise, the dorsum of E. pearsei is bluish slate black or blackish slate (vs. grayish in E. corumbaensis). The dorsum of E. corumbaensis in live specimens is also grayish, with scattered, minute white dots (vs. dark gray with very light gray speckling in E. surinamensis). The venter is gray or brown with white spots (venter immaculate in E. bicolor, E. haroi, E. helianneae, E. matogrosso, and E. muiraquitan; gray with whitish blotches or spots in $E$. bumbameuboi, E. carvalhoi, E. cesarii, E. panamensis, and E. surumu; yellow with black blotches in E. erythrogaster; mottled gold and gray in E. surinamensis; carrot red in E. pearsei and white with gray spots in E. magnus). Elachistocleis corumbaensis also has large, irregular light cream spots on its groin (vs. not spotted in E. haroi, E. helianneae, and E. panamensis) and a thin mid-longitudinal light stripe from the post-cephalic transverse skinfold to the vent may be present (vs. stripe absent in $E$. bicolor, E. bumbameuboi, E. carvalhoi, E. piauiensis, and E. surumu).

Description of holotype.-Adult male. Measurements in Table 1. General aspect ovoid, skin slightly rough. Head small, head length $21.8 \%$ of snout-vent length, $91.3 \%$ of head width. Snout prominent, slightly projecting beyond mouth, protruding in lateral view. Snout sub-elliptical when viewed from above. Eyes small, dorsolateral, laterally directed, slightly prominent. Nostrils small, anterolateral. Canthus rostralis rounded, slightly convex. Loreal region slightly concave. Postcommissural glands poorly developed. Interorbital space slightly convex. Poorly defined incomplete occipital fold across back of 

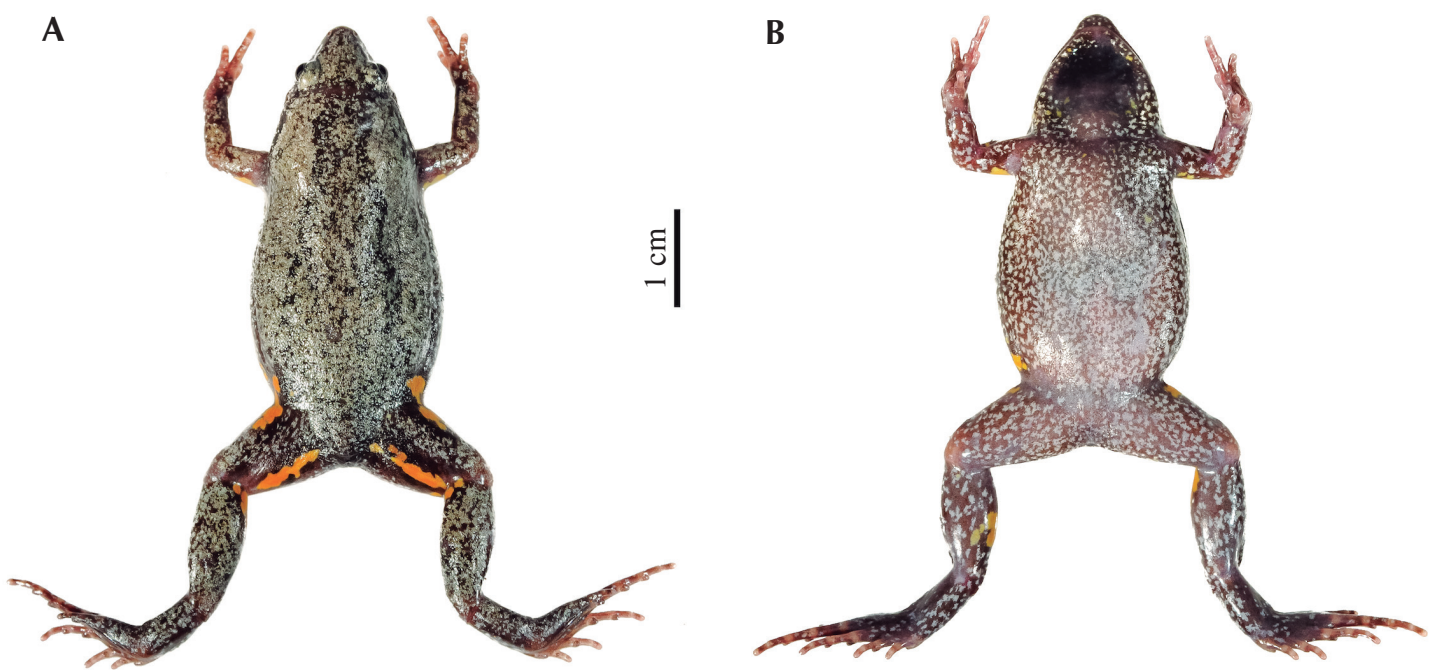

Figure 1. Dorsal (A) and ventral (B) views of the holotype of Elachistocleis corumbaensis (ZUFMS-AMP 924), Parque

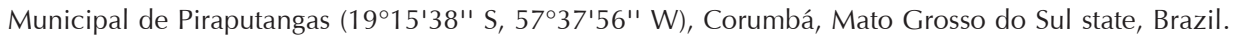
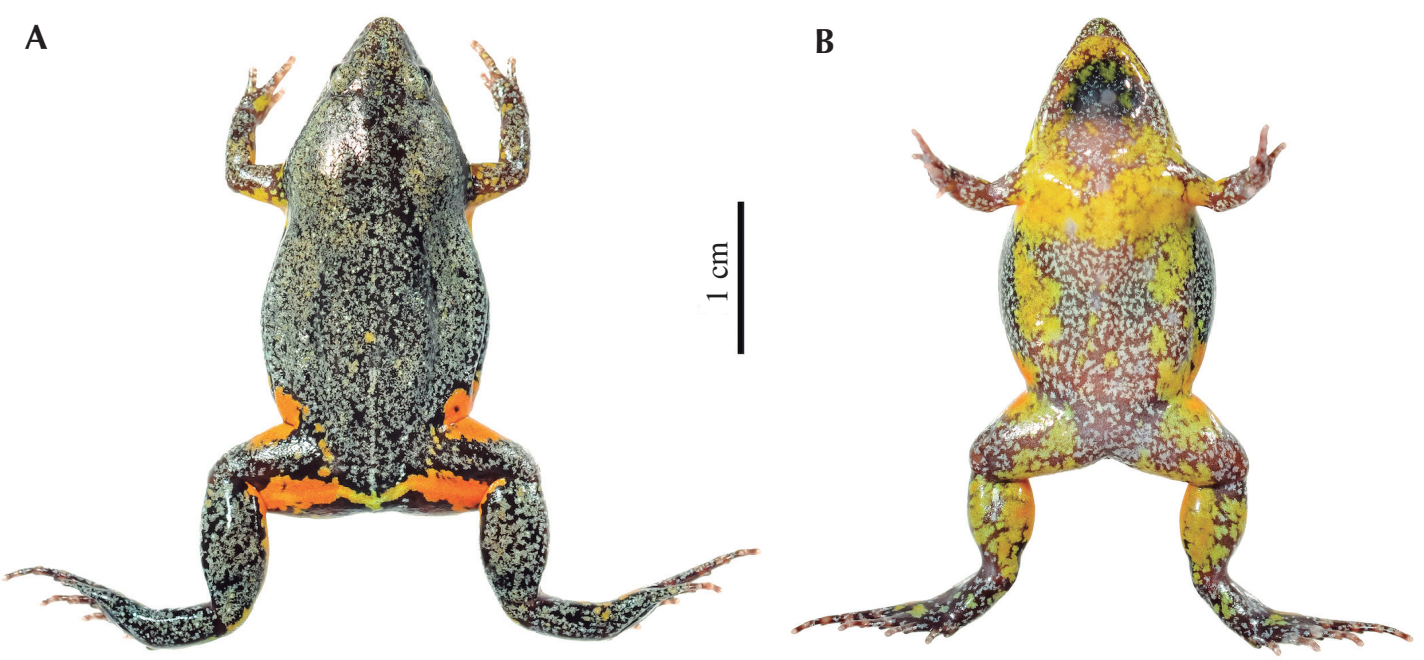

Figure 2. Dorsal (A) and ventral (B) views of the paratype of Elachistocleis corumbaensis (ZUFMS-AMP 923), Parque

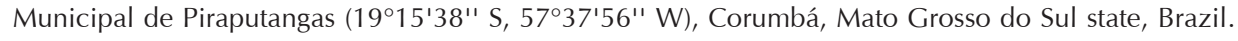

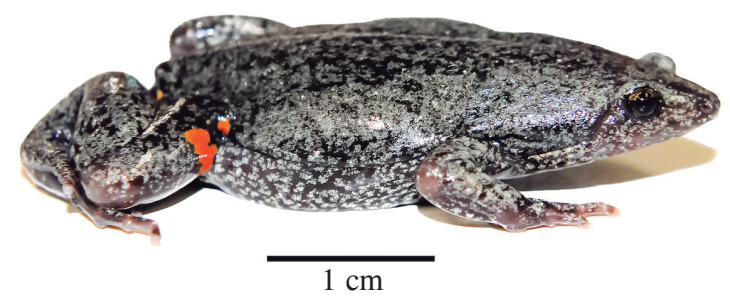

Figure 3. Lateral view of the paratype of Elachistocleis corumbaensis (MNRJ 91001), Parque Muni-

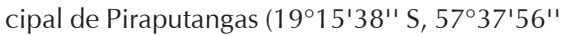
W), Corumbá, Mato Grosso do Sul state, Brazil. 


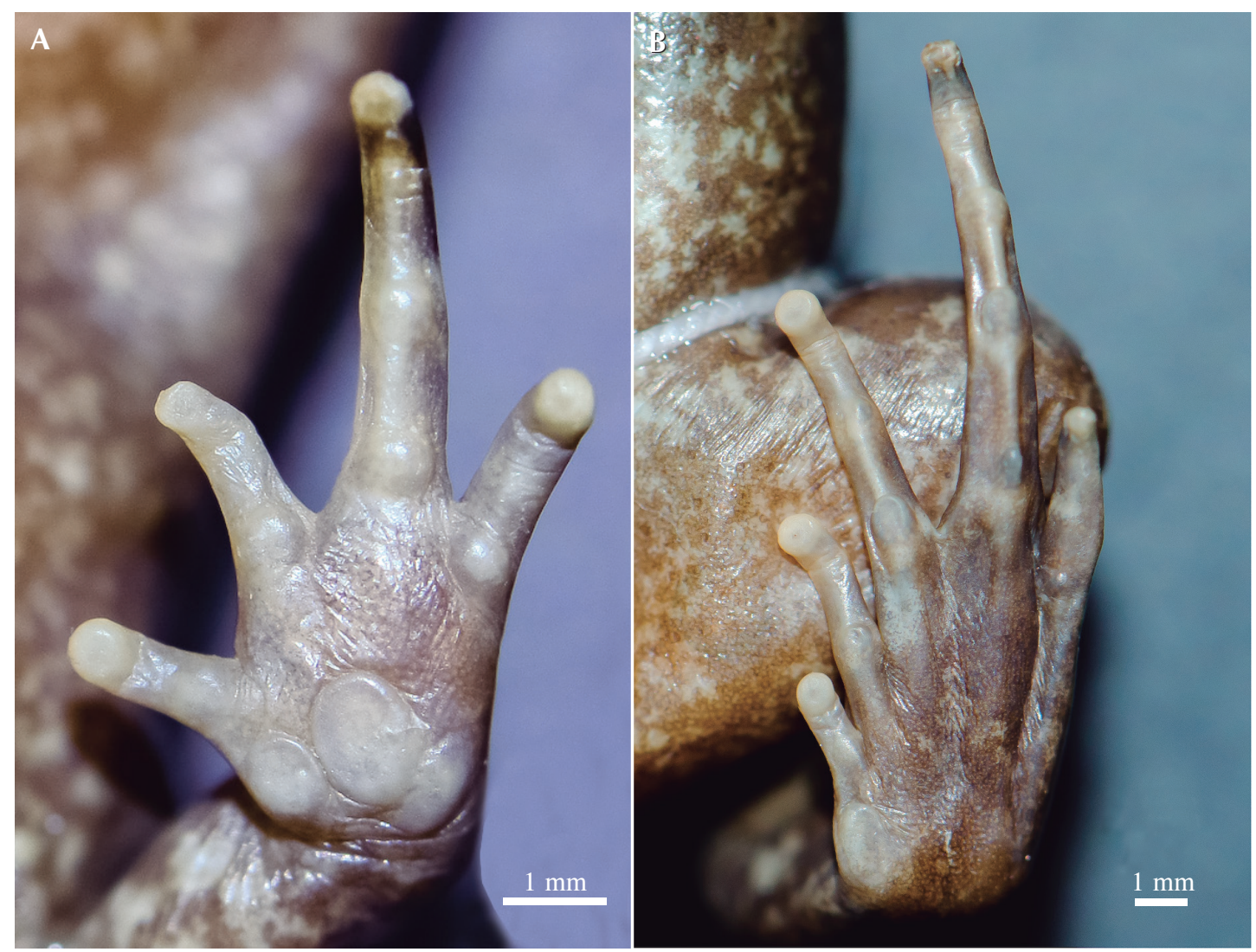

Figure 4. Palmar (A) and plantar (B) views of left hand and foot of the paratype of Elachistocleis corumbaensis

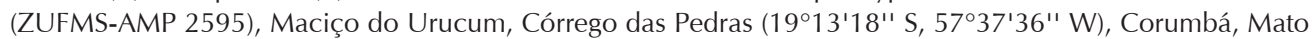
Grosso do Sul state, Brazil.

notched posteriorly. Vocal slits present. Premaxillary, maxillary, and vomerine odontophores absent. Upper jaw projecting beyond lower jaw. Vocal sac distinct, subgular, not expanded externally.

Arms moderately robust, short. No tubercles or crests on forearm. Fingers robust, short, free. Relative lengths of fingers: I $<$ IV $<$ II $<$ III. Fingers with round, flat subarticular tubercles. Palmar tubercle round, longitudinally divided, about two times larger than thenar tubercle. Supernumerary tubercles absent. Lateral fringe on fingers present as weak ridge. Prepollex not evident. Tubercles absent from knee, heel, and tarsus. Tarsal fold absent. Legs short, robust. Thigh larger than shank, but shorter than foot length. Toes robust, free. Relative toes lengths: I $<$ II $<$ V $<$ III $<$ IV. Subarticular tubercles round, flat. Supernumerary plantar tubercles absent. Lateral fringe on toes present as weak ridge. Inner metatarsal tubercle longer than wide, oval, flat. Outer metatarsal tubercle absent. Toes tips not expanded into pads. Tips of fingers and toes without discs or terminal grooves.

Dorsum slightly rough in preservative, grayish, with scattered minute white dots, and large, elongate darkish spot on the mid-dorsum and posterior region of head; venter gray with 
Table 1. Morphometric variation (in $\mathrm{mm}$ ) of the holotype and paratypes of Elachistocleis corumbaensis.

\begin{tabular}{|c|c|c|c|c|}
\hline & $\begin{array}{c}\text { Holotype } \\
\text { ZUFMS-AMP } 923 \\
\text { male }\end{array}$ & $\begin{array}{c}\text { Paratype } \\
\text { MNRJ } 91001 \\
\text { male }\end{array}$ & $\begin{array}{c}\text { Paratype } \\
\text { ZUFMS-AMP } 924 \\
\text { male }\end{array}$ & $\begin{array}{c}\text { Paratype } \\
\text { ZUFMS-AMP } 2595 \\
\text { female }\end{array}$ \\
\hline Snout-vent length & 31.4 & 30.8 & 26.9 & 40.3 \\
\hline Axilla-groin length & 14.2 & 13.8 & 11.2 & 20.5 \\
\hline Head length & 6.8 & 6.7 & 5.52 & 7.4 \\
\hline Head width & 7.5 & 7.3 & 6.2 & 8.8 \\
\hline Eye diameter & 1.9 & 1.9 & 1.7 & 2.0 \\
\hline Upper eyelid width & 0.9 & 0.9 & 0.9 & 1.1 \\
\hline Eye-naris distance & 2.4 & 2.4 & 2.0 & 2.7 \\
\hline Interorbital distance & 3.8 & 3.6 & 3.5 & 4.3 \\
\hline Internarial distance & 1.4 & 1.4 & 1.3 & 1.9 \\
\hline Snout length & 3.3 & 3.4 & 2.9 & 3.9 \\
\hline Humerus length & 4.8 & 4.2 & 3.7 & 3.1 \\
\hline Forearm length & 5.0 & 4.9 & 4.0 & 6.3 \\
\hline Hand length & 6.4 & 5.9 & 5.1 & 8.3 \\
\hline Thigh length & 11.6 & 11.4 & 9.8 & 13.9 \\
\hline Shank length & 10.5 & 10.4 & 9.1 & 13.0 \\
\hline Foot length & 12.1 & 11.9 & 10.5 & 15.8 \\
\hline
\end{tabular}

white spots separating the dorsal and ventral regions; vocal sac dark; a large, irregular light cream spot on humerus; large, irregular light cream spots on groin; irregular light cream stripe on posterior surface of each thigh; irregular, light cream spots on the proximal internal surface of each shank.

Color in life of holotype.-Grayish above with no distinct line or stripe, and with scattered minute white dots; two small yellow spots in anterior region of dorsum; single vocal sac darker than chest and venter; about 12 small yellow spots on vocal sac and lower maxilla; ventral and inguinal regions gray with white spots separating dorsum from venter; large, irregular light yellow spot on anterior surface of each humerus; large, irregular, light yellow spots on groin; narrow, irregular, light orange stripe on posterior surface of thighs; irregular, light orange spots on proximal internal surface of shank.

Color pattern variation in live specimens.The type series includes three adult males and one adult female, which resemble one another in shape, size, and color. Some variation is present in size of the spots and width of the orange stripes on the posterior surfaces of thighs. ZUFMS-AMP 923 (Figure 2 A, B) possesses a wide, irregular, and continuous light orange stripe on posterior surfaces of thighs and shanks; this stripe is reduced and discontinuous in the holotype and MNRJ 91001. The anterior surfaces of thighs and shanks of ZUFMS-AMP 923 are heavily pigmented with unevenly scattered yellow spots. Hands and feet of ZUFMS-AMP 923 have small yellow spots. MNRJ 91001 (Figure 3) and ZUFMS-AMP 923 bear a thin 
mid-longitudinal light stripe from the postcephalic transverse skinfold to the vent. The single female paratype (ZUFMS-AMP 2595) is the largest specimen. The female's dorsum and dorsal surfaces of the limbs are smooth, brown, with minute scattered pores in dorsolateral and inguinal regions. The dorsal surfaces bear numerous small dermal spines around the cloacal opening and the venter is brown with light spots. The throat is darker brown than the venter; three light spots are present above the inguinal region and a narrow, irregular, light cream spot is located on the posterior surface of the left thigh. Figure 4 A, B shows the typical number and distribution of tubercles on the hand and foot of E. corumbaensis, and Table 1 summarizes the morphometric variation among the holotype and the three paratypes.
Distribution and natural history.Elachistocleis corumbaensis is known only from the Parque Municipal de Piraputangas and the Maciço do Urucum, located in the western part of the Pantanal (Figure 5). This region has high biological diversity and its natural habitats are threatened by anthropogenic activities, such as conversion to pasture or mining activities. Furthermore, the western border of the Pantanal and Maciço do Urucum are considered priority areas for biodiversity conservation (Tomas et al. 2010). Male specimens (MNRJ 91001, ZUFMSAMP 923, ZUFMS-AMP 924) were found in small bodies of water accumulated in soils characterized by large rocks. Heavy rainfall has eroded much of the original habitat, converting the area into bare soil with scattered patches of shrubs and grass. Two permanent ponds with

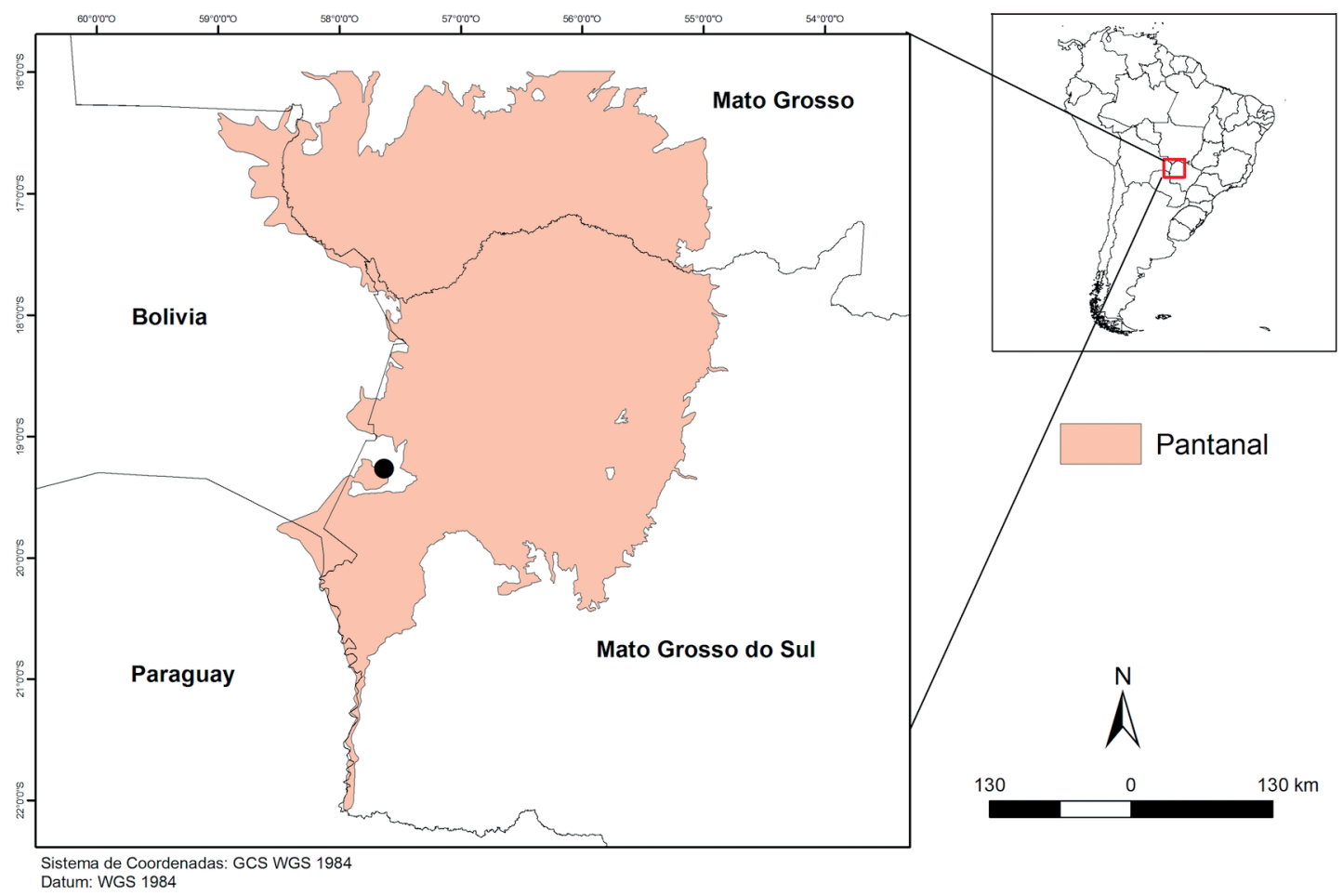

Figure 5. Distribution of Elachistocleis corumbaensis. The type locality and location from which the female paratype was collected are virtually the same. 
herbaceous vegetation are predominantly composed of grasses, and several temporary ponds form occasionally by accumulation of rainfall. Male specimens were observed vocalizing at night (between 19:00 and 20:00 hr); vocalizations were not recorded. ZUFMS-AMP 2595 was collected in the seasonal alluvial forest of Córrego das Pedras formation (of unknown but probably late pre-Cambrian or early Paleozoic age, Dorr 1945).

Etymology.-The specific name, a noun in apposition, refers to the city of Corumbá, the westernmost and northernmost city in the state of Mato Grosso do Sul. Corumbá is the largest municipality in area in the state, composing $18 \%$ of its territory. Further, $95.6 \%$ of Corumbá is located within the Pantanal ecosystem (Silva and Abdon 1998).

\section{Discussion}

Despite the relatively high diversity of amphibians (44 species; Strüssmann et al. 2011 and references therein), the anuran fauna of Pantanal is still poorly known taxonomically (Souza et al. 2017). Pioneering works by Cope (1868), Parker (1928), and Bokermann (1962) and several recent works (e.g., Uetanabaro et al. 2008, Ávila et al. 2010, Caramaschi 2010, Souza et al. 2017) provided substantial information on the distribution, variation, and description of many species in the ecosystem. However, commonly anurans are identified only to the generic level in the literature (e.g., Strüssmann et al. 2000, 2011, Uetanabaro et al. 2007, 2008), which reinforces the necessity of further taxonomic studies.

The first comprehensive field guide to anurans of Pantanal and adjacent Cerrados reported 56 species representing nine families (Uetanabaro et al. 2008). Among these, one species of Elachistocleis, depicted and briefly described, was noted as undescribed. Based on the color pattern described (Uetanabaro et al. 2008: 173) for the species listed as "Elachis- tocleis sp.", we assigned that specimen to $E$. corumbaensis.

Possibly Elachistocleis cf. bicolor and Elachistocleis cf. ovalis, as described in Uetanabaro's field guide, represent other undescribed species. The Latin abbreviation "cf." (= compared to) has been used extensively in reference to Elachistocleis in Pantanal (e.g., Strüssmann et al. 2000, 2011, Rodrigues et al. 2003, Uetanabaro et al. 2007, Piatti et al. 2010, Alho 2011), where identification of the species seems to be uncertain; see also Caramaschi (2010) for alternate names of all populations previously referred to E. ovalis in Brazil.

The description of E. corumbaensis increases the number of Oval frogs reported from Mato Grosso do Sul to four (see Souza et al. 2017), and the number of species of Elachistocleis in the Brazilian Pantanal to four species that are readily distinguished by their ventral coloration. The discovery of E. corumbaensis demonstrates the value of the single protected area in Corumbá for biodiversity conservation and the importance of continuing field work in the western part of the Pantanal to investigate its herpetofauna.

\section{Acknowledgments}

Fundação de Meio Ambiente do Pantanal permitted research to be conducted at Parque Municipal de Piraputangas. Gustavo Graciolli (UFMS) granted access to the ZUFMS-AMP specimens used in this study; Felipe Toledo (ZUEC), W. Ronald Heyer (USNM), and Hussam Zaher (MZUSP) provided use of specimens for comparisons. Two anonymous reviewers read and improved the manuscript. Linda Trueb edited an early version of the manuscript. We also thank Janalee Caldwell for English review. Maxwell Oliveira prepared the map depicted in Figure 5. NA thanks Gecele Paggi (UFMS) for her continuous support and encouragement during the writing of this manuscript. The Coordenação de Aperfeiçoamento de Pessoal de Nível Superior (CAPES) provided a fellowship to Alessandher Piva 
during his graduate studies at the Universidade Federal de Mato Grosso do Sul; Conselho Nacional de Desenvolvimento Científico e Tecnológico (CNPq) provided funding to Ulisses Caramaschi.

\section{References}

Alho, C. J. R. 2011. Biodiversity of the Pantanal: its magnitude, human occupation, environmental threats and challenges for conservation. Brazilian Journal of Biology 71: 229-232.

Ávila, R. W., A. Pansonato, and C. Strüssmann. 2010. A new species of the Rhinella margaritifera group (Anura: Bufonidae) from Brazilian Pantanal. Zootaxa 2339: 57-68.

Bokermann, W. C. A. 1962. Sôbre uma pequena coleção de anfibios do Brasil Central, com a descrição de uma espécie nova de Physalaemus (Amphibia, Salientia). Revista Brasileira de Biologia 22: 213-219.

Caramaschi, U. 2010. Notes on the taxonomic status of Elachistocleis ovalis (Schneider, 1799) and description of five new species of Elachistocleis Parker, 1927 (Amphibia, Anura, Microhylidae). Boletim do Museu Nacional, Nova Série, Zoologia 527: 1-30.

Cei, J. M. 1980. Amphibians of Argentina. Monitore Zoologico Italiano 2: 1-609.

Cole, C. J., C. R. Townsend, R. P. Reynolds, R. D. MacCulloch, and A. Lathrop. 2013. Amphibians and reptiles of Guyana, South America: illustrated keys, annotated species accounts, and a biogeographic synopsis. Proceedings of the Biological Society of Washington 125: 317-578.

Cope, E. D. 1868. An examination of the Reptilia and Batrachia obtained by the Orton Expedition to Ecuador and the Upper Amazon, with notes on other species. Proceedings of the Academy of Natural Sciences of Philadelphia 20: 96-140.

de Sá, R. O., J. W. Streicher, R. Sekonyela, M. C. Forlani, S. P. Loader, E. Greenbaum, S. Richards, and C. F. B. Haddad. 2012. Molecular phylogeny of microhylid frogs (Anura: Microhylidae) with emphasis on relationships among New World genera. BMC Evolutionary Biology 12: $241-262$.

Dorr, J. V. N. 1945. Manganese and iron deposits of Morro do Urucum, Mato Grosso, Brazil. U.S. Geological Survey Bulletin 946-A: 1-47.
Frost, D. R. 2017. Amphibian Species of the World: an Online Reference. Version 6.0 (28 August 2017). Electronic Database accessible at http://research.amnh. org/herpetology/amphibia/index.html/American Museum of Natural History, New York, USA. Captured on 29 August 2017.

Heyer, W. R., A. S. Rand, C. A. G. Cruz, O. L. Peixoto, and C. E. Nelson. 1990. Frogs of Boracéia. Arquivos de Zoologia 31: 237-410.

Jansen, M., R. Bloch, A. Schulze, and M. Pfenninger. 2011. Integrative inventory of Bolivia's lowland anurans reveals hidden diversity. Zoologia Scripta 40: 567-583.

Lavilla, E. O., M. Vaira, and L. Ferrari. 2003. A new species of Elachistocleis (Anura: Microhylidae) from the Andean Yungas of Argentina, with comments on the Elachistocleis ovalis - E. bicolor controversy. AmphibiaReptilia 24: 269-284.

Nunes-de-Almeida, C. H. L. and L. F. Toledo. 2012. A new species of Elachistocleis Parker (Anura, Microhylidae) from the State of Acre, Northern Brazil. Zootaxa 3424: 43-50.

Parker, H. W. 1928. Notes on reptiles and batrachians from Matto Grosso and eastern Bolivia. Annals and Magazine of Natural History 10: 96-99.

Peel, M. C., B. L. Finlayson, and T. A. Mcmahon. 2007. Updated world map of the Köppen-Geiger climate classification. Hydrology and Earth System Sciences 11: $1633-1644$.

Pereyra, L. C., M. S. Akmentins, G. Laufer, and M. Vaira. 2013. A new species of Elachistocleis (Anura: Microhylidae) from north-western Argentina. Zootaxa 3694: 525-544.

Piatti, L., F. L. Souza, and P. Landgref-Filho. 2010 Anuran assemblage in a rice field agroecosystem in the Pantanal of Central Brazil. Journal of Natural History 44: 12151224.

Piva, A. 2014. Diversidade de anfíbios anuros (Anura) em uma área de floresta estacional semidecidual no Parque Municipal de Piraputangas, em Corumbá, MS. Unpublished M.Sc. Dissertation. Universidade Federal de Mato Grosso do Sul, Brazil.

Rodrigues, D.J., F. S. Lopes, and M. Uetanabaro. 2003. Padrão reprodutivo de Elachistocleis cf. bicolor Valenciennes, 1838 (Amphibia: Anura) na Serra da Bodoquena, MS. Iheringia, Série Zoologia 93: 365371.

Ruthven, A. G. 1914. Description of a new engystomatid frog of the genus Hypopachus. Proceedings of the Biological Society of Washington 27: 77-80. 
Silva, J. S. V. and M. M. A. Abdon. 1998. Delimitação do Pantanal brasileiro e suas sub-regiões. Pesquisa Agropecuária Brasileira, Número Especial 33: 1703 1711.

Souza, F. L., C. P. A. Prado, J. L. M. M. Sugai, V. L. Ferreira, C. Aoki, P. Landgref-Filho, C. Strüssmann, R. W. Ávila, D. J. Rodrigues, N. R. Albuquerque, J. Terra, M. Uetanabaro, A. F. Béda, L. Piatti, R. A. KawashitaRibeiro, M. Delatorre, G. P. Faggioni, S. D. B. Demczuk, and S. Duleba. 2017. Diversidade de anfíbios do Estado de Mato Grosso do Sul, Brasil. Iheringia, Série Zoologia 107(supl.): 1-10.

Strüssmann, C., C. P. A. Prado, M. Uetanabaro, and V. L. Ferreira. 2000. Amphibians and reptiles of selected localities in the southern Pantanal floodplains and neighboring Cerrado areas, Mato Grosso do Sul, Brasil. Pp. 98-102 in P. W. Willink, B. Chernoff, L. E. Alonso, J. R. Montambault, and R. Lourival (eds.), A Biological Assessment of the Aquatic Ecosystems of the Pantanal, Mato Grosso do Sul, Brasil. Washington. RAP Bulletin of Biological Assessment 18. Conservation International.

Strüssmann, C., C. P. A. Prado, V. L. Ferreira, and R. A. Kawashita-Ribeiro. 2011. Diversity, ecology, management and conservation of amphibians and reptiles of the Brazilian Pantanal: a review. Pp. 495519 in W. J. Junk, C. J. da Silva, C. Nunes-da-Cunha, and K. M. Wantzen (eds.), The Pantanal: Ecology,
Biodiversity and Sustainable Management of a Large Neotropical Seasonal Wetland. Sofia. Pensoft Publishers.

Toledo, L. F. 2010. A new species of Elachistocleis (Anura; Microhylidae) from the Brazilian Amazon. Zootaxa 2496: 63-68.

Toledo, L. F., D. Loebmann, and C. F. B. Haddad. 2010. Revalidation and redescription of Elachistocleis cesarii (Miranda-Ribeiro, 1920) (Anura: Microhylidae). Zootaxa 2418: 50-60.

Tomas, W. M., I. H. Ishii, C. Strüssmann, A. P. Nunes, S. M. Salis, Z. Campos, V. L. Ferreira, M. O. Bordignon, A. T. M. Barros, and D. R. C. Padilha. 2010. Borda oeste do Pantanal e Maciço do Urucum em Corumbá, MS: área prioritária para conservação da biodiversidade. Pp. 1-6 in W. M. Tomas (coord.), Anais do $5^{\circ}$ Simpósio sobre Recursos Naturais e Socioeconômicos do Pantanal. Corumbá. Embrapa Pantanal, UFMS.

Uetanabaro, M., F. L. Souza, P. Landgref-Filho, A. F. Beda, and R. A. Brandão. 2007. Anfíbios e répteis do Parque Nacional da Serra da Bodoquena, Mato Grosso do Sul, Brasil. Biota Neotropica, 7: 279-289.

Uetanabaro, M., C. P. A. Prado, D. J. Rodrigues, M. Gordo, and Z. Campos. 2008. Guia de campo dos anuros do Pantanal e planaltos de entorno - Field guide to the anurans of Pantanal and surrounding cerrados. Cuiabá. Editora da UFMS. 196 pp. 
Piva et al.

Appendix I. Comparative material examined.

Elachistocleis bicolor: BRAZIL: Mato Grosso do Sul: Corumbá, Fazenda Santa Clara (ZUFMS-AMP 1703); Ponta Porã, Inhuverá (MNRJ 6955).

Elachistocleis bumbameuboi: BRAZIL: MARANHÃO: São Luís, UHE Ponta da Madeira (MNRJ 53200, holotype; MNRJ 53201-53205, 53378, paratypes).

Elachistocleis carvalhoi: BRAZIL: Tocantins: Aragominas (MNRJ 51384, holotype; MNRJ 51385, paratype); Nova Olinda (MNRJ 51386, paratype); Santa Fé do Araguaia (MNRJ 48220, paratype). PARÁ: Canaã dos Carajás, Mineração Serra do Sossego (MNRJ 52474, paratype); Marabá, Reserva Mãe Maria (MNRJ 52734, paratype); Parauapebas, Serra dos Carajás (MNRJ 58858, paratype); Piçarra (MNRJ 51387, paratype); São Geraldo do Araguaia (MNRJ 60285, paratype).

Elachistocleis cesarii: BRAZIL: São Paulo: Botucatu, Fazenda Dinucci (MNRJ 61116, 66851); Botucatu (MNRJ 66858, 66860, 66862-66869); Campinas, Souzas (MNRJ 34698); Pedro de Toledo (MNRJ 7020); Rubião Júnior (MNRJ 49643, 66854-66855, 66859); São Manuel, Estação Experimental de São Manoel (MNRJ 66857).

Elachistocleis erythrogaster: BRAZIL: Rıo Grande do Sul: São Francisco do Sul, Pró-Mato, Potreiro Novo (MNRJ 39098, ex-MCP 3142, paratype).

Elachistocleis helianneae: BRAZIL: AmAzONAs: Humaitá (MNRJ 6989, holotype; MNRJ 4818-4820, 4822, 6990-6993, 66870-66895, paratypes).

Elachistocleis magnus: BRAZIL: RondônIA: Espigão do Oeste, Fazenda Jaburi (MNRJ 80024, ex-ZUEC 11381, paratype).

Elachistocleis matogrosso: BRAZIL: MAto Grosso: Cuiabá (MNRJ 4812, holotype; MNRJ 4813, MNRJ 6994, MNRJ 43841, paratypes); Primavera (MNRJ 6977, paratype); Barão de Melgaço, RPPN SESC Pantanal (MNRJ 3288032882, paratypes). Mato Grosso do Sul: Porto Murtinho, Fazenda Patolá (ZUFMS-AMP 1050).

Elachistocleis muiraquitan: BRAZIL: ACRE: Xapuri (ZUEC 5666, holotype; ZUEC 5657-5665, ZUEC 5667, ZUEC 5742-5743, ZUEC 5751, paratypes).

Elachistocleis pearsei: COLOMBIA: META: (USNM 15167-15176); Villavicencio (USNM 152204-152208).

Elachistocleis piauiensis: BRAZIL: PIAUí: Picos, BR 316, km 312 (MNRJ 66848, ex-JJ 6024, holotype; MNRJ 14253, 60086, ex-JJ 6025-6026, paratypes); Brejo do Piauí (MNRJ 42073).

Elachistocleis surinamensis: SURINAME: Langamankondre (MZUSP 36418-36427).

Elachistocleis surumu: BRAZIL: RoraIma: Pacaraima, Vila Surumu (MNRJ 25210, holotype; MNRJ 2521125300, 25302-25305, 25307-25326, 25338-25344, paratypes).

Elachistocleis sp.: BRAZIL: MAto Grosso do Sul: Miranda, Fazenda São Francisco (ZUFMS-AMP 967), Porto Murtinho, Fazenda Patolá (ZUFMS-AMP 970, ZUFMS-AMP 1042), Corumbá, MS-184 (ZUFMS-AMP 1240). Corumbá, Fazenda Nhumirim (ZUFMS-AMP 1221). 